Ilmenau University of Technology

Institute of Economics

Ilmenau Economics Discussion Papers, Vol. 26, No. 137

The Battle of YouTube, TV and Netflix An Empirical Analysis of Competition in Audiovisual Media Markets

Oliver Budzinski, Sophia Gaenssle \& Nadine LindstädtDreusicke

April 2020

Institute of Economics

Ehrenbergstraße 29

Ernst-Abbe-Zentrum

D-98 684 Ilmenau

Phone 03677/69-4030/-4032

Fax 03677/69-4203

https://www.tu-ilmenau.de/wpo/forschung/

ISSN 0949-3859 


\title{
The Battle of YouTube, TV and Netflix - An Empirical Analysis of Competition in Audiovisual Media Markets
}

\author{
Oliver Budzinski\#, Sophia Gaenssle ${ }^{+}$\& Nadine Lindstädt-Dreusicke*
}

\begin{abstract}
The world of audiovisual online markets is rapidly changing. Not long ago, it was dominated by linear television, transmitted terrestrially, through cable networks or via satellite. Recently, streaming services like Netflix, YouTube, Amazon Prime and others have emerged as new suppliers of audiovisual content. In this quickly changing industry, competition interrelations between such different formats like traditional TV, videos on YouTube, and streaming via Netflix are subject to controversy. In particular, doubt is cast on services like YouTube exerting competitive pressure on services like Netflix and traditional TV. Based upon a survey with almost 3,000 participants, we provide an empirical analysis of consumption behavior of audiovisual contents. Using descriptive and analytical statistics, including multiple equation models, we show that there are specific areas within audiovisual content markets where YouTube exerts considerable competitive pressure on both Netflix and classic TV, for instance, through prime time video entertainment. However, our analysis yields differentiated results as we also identify areas where competition intensity between different service types appear to be low, for instance, through daytime and regarding the intention to shorten waiting time.
\end{abstract}

Keywords: video-on-demand, streaming markets, media economics, cultural economics, commercial television, multiple equation models, competition, consumption behavior

JEL-Codes: L82, L86, Z10, M21, L13, L40, L51, C39

\# Professor of Economic Theory, Institute of Economics \& Institute of Media and Mobile Communication, Department of Economics and Media, IImenau University of Technology, Germany, oliver.budzinski@tu-ilmenau.de

+ M.Sc. in Media Economics, Institute of Economics, Department of Economics and Media, Ilmenau University of Technology, Germany, sophia.gaenssle@tu-ilmenau.de

* Professor of Media Management and Marketing, Business School at Pforzheim University, Germany, nadine.lindstaedt-dreusicke@hs-pforzheim.de

We thank Thomas Apolte, Thomas Grebel, Stefan Heyder and the participants of the European Media Management Conference (Limassol, June 2019) and of Radein Reseach Seminar (Radein, February 2020) for valuable comments on an earlier version of the paper. Special thanks to the Office for Gender Equity (TU IImenau) for supporting the conference attendance of Sophia Gaenssle. Furthermore, we thank Valentina Wenzel, Charlotte Volk, Julia Diana Adschalow and Janine Dietz for valuable assistance. 


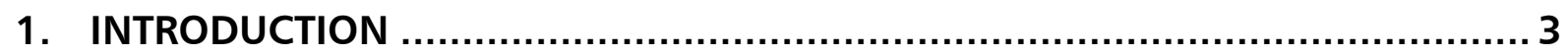

2. AUDIOVISUAL MARKETS AND COMPETITION ....................................... 6

3. EMPIRICAL ANALYSIS OF AUDIOVISUAL MEDIA CONSUMPTION.............. 11

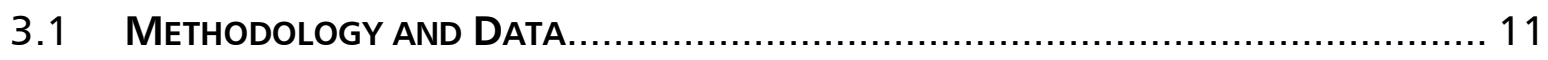

3.1.1 Sampling and Data ............................................................. 11

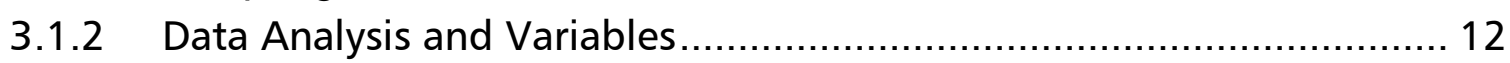

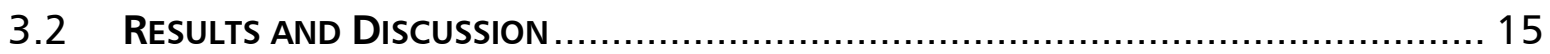

3.2.1 Descriptive Statistics and Results ........................................... 15

3.2.2 Econometric Analysis and Results........................................... 18

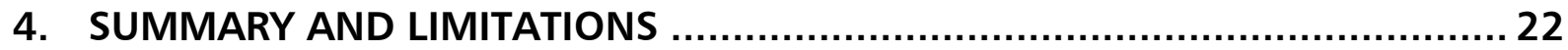

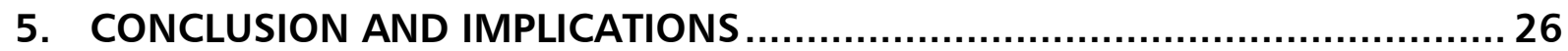

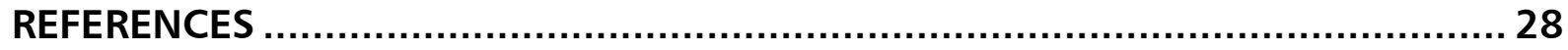




\section{Introduction}

The consumption of audiovisual content is rapidly changing. While traditional television (TV) still dominates the consumption of audiovisual contents of an older age audience, the younger ages already devote more time to consuming audiovisual contents via online streaming services and video portals like Netflix or YouTube (also referred to as video-on-demand; VoD). This development is also driven by an increased use of mobile devices such as smartphones and tablets, allowing for considerably enhanced options of consuming audiovisual contents in not only the living room at home but also virtually everywhere and every time. User figures and viewing numbers from various countries show that particularly younger generations extensively use portals like YouTube and watch online streaming services like Netflix, whereas older age groups (50+ years) significantly less switch on these services (see, inter alia, for Germany Lindstädt-Dreusicke \& Budzinski 2020, for Scandinavia Audience Project 2019, for the UK Fisher 2019, and for the US Richter 2019). At the same time, traditional television is not only relatively stronger with the older population (e.g. due to a lack of mobile consumption of non-TV contents like YouTube videos) but also in absolute terms. In 2019, the average daily viewing time of television in the $50+$ age groups amounted to 318 minutes per day, whereas the 30-49 years-old watched 176 minutes per day and the 14-29 years-old only 82 minutes per day. Also, consumption time in the older age group slightly increased whereas it decreased in the younger age clusters, particularly within the 30-49 years old (-18 minutes per day compared to previous year) (Statista 2020). Thus, the figures do not allow disentangling how much of the dynamics results from complementary services in the mobile online world and how much from viewers abandoning traditional television and switching to various VoD formats.

In line with the more widespread usability of mobile internet, some of the online services are predominantly popular for shorter video contents like YouTube, whereas others (like Netflix) mirror more closely the content that traditional television is broadcasting. The types of contents differ in various regards including average lengths of videos, share of sequels and movies, entertainment categories, extent of 
exclusive and/or original content ${ }^{1}$, etc. $\mathrm{VoD}$, in general, differs from TV in that there is no fixed program schedule as a take-it-or-leave offer for consumers. Instead, VoD consumers can watch all available contents whenever they want and compile their "program" by themselves. The media literature calls the schedule-bound service linear and the on-demand type non-linear (inter alia, Berman et al. 2009; Kazakova \& Cauberghe 2013; Steemers 2014; van den Bulck \& Enli 2014; Simons 2015; Enli \& Syvertsen 2016).

The currently relevant online services differ in terms of business models from both traditional TV and from each other. In terms of business models, advertisedfinanced streaming services (AVoD; e.g. YouTube) can be distinguished from paidfor (by users) streaming services (PVoD; e.g. Netflix) (Lindstädt-Dreusicke \& Budzinski 2020). While it is possible that streaming services mix these models (i.e. hybrid models, like Spotify is doing in respect to audio streaming services), at the time of our empirical analysis (winter 2018/19), the relevant suppliers in the German market were predominantly devoted to one of the two models. ${ }^{2}$ Obviously, business models will develop and change along with the high dynamics of the markets in question. Therefore, for the purpose of our analysis, we decided to directly pick two of the most prominent online services for the consumption of audiovisual contents, namely YouTube and Netflix, and compare them to traditional television (the latter with almost no dynamics regarding the main providers; Budzinski \& Lindstädt-Dreusicke 2020). While YouTube was and remains an obvious choice, it is

1 Netflix and Amazon Prime Video for instance, as well as new players, such as Disney+ and Apple $\mathrm{TV}+$ that just recently entered the VoD sector aim at attracting their audience especially with original (own produced) programming (e.g. Netflix with House of Cards or Orange is the New Black) or at least content, where they hold exclusive rights for (inter alia, Aguiar \& Waldfogel 2018; Benes 2019). By doing so, they both create a competitive advantage over other VoD providers and also make a clear comparability of different VoD services for the users more difficult.

2 YouTube started its paid-for service only in mid-2018, just before our data was collected, but it was hardly known or used at the time (YouTube Official Blog 2018). Moreover, until today, YouTube is predominantly known for its AVoD service. In addition to this, it had been announced in September 2019 that a lot of own productions that had been set behind the Premium Paywall will be moved to the advertising-financed section of YouTube, leading to speculations about the success and performance of the paid-for service offer (Meedia 2019). Joyn, a VoD service by ProSiebenSat.1. and Discovery started in June 2019 with an AVoD model only and just switched to a hybrid model of both advertising and user financing at the end of 2019, both after our data had been collected. TV Now, a hybrid service by the RTL Group had been existent before, however, had little meaning in the German VoD market compared to the market leaders Netflix and Amazon Prime Video and just in 2019 announced massive investments in its video streaming activities for the next three years (Krei 2019, W\&V 2019). 
not that obvious regarding PVoD-services. According to the Audience Project (2019), Netflix is taking the leading position among the most used streaming and downloading services for the US, UK, Germany, Denmark, Sweden and Norway. For the US and Germany, Netflix is followed by Amazon Prime Video, whereas in the UK the BBC iPlayer takes the second position from Amazon Prime Video. In the Scandinavian countries, by contrast, Amazon Prime Video plays a fairly little role. Virtually all available market share figures assume separate markets for services like YouTube and PVoD streaming services (thus, ignoring YouTube when calculating shares for Netflix and co). As of October 2019, market shares according to subscription figures in Germany display Amazon Prime Video (47 percent) leading from Netflix (36 percent) with other providers clearly lacking behind (e.g Sky with 5.9 percent) (Herrmann 2019). However, Amazon ties its Prime subscription to a bundle of different services (e.g. free shipping, next day delivery, music streaming, video streaming), thus, it is not clear how many people exactly use Amazons VoD offer (EI Khaoudi 2018). Based on daily usage figures, Netflix is leading the market in Germany, followed by Amazon Prime Video (Herrmann 2019).

Despite the differences in content, business models and treatment by available empirical studies, at the end of the day, all of TV, AVoD and PVoD are offering audiovisual contents to the consumers. In the light of the increasing importance of online streaming services vis-à-vis traditional TV, therefore, the questions arise whether relevant competitive pressure between the services (in our study represented by YouTube, Netflix, TV) exists. We specify this general research question by, more precisely, inquiring whether the intensity of competitive pressure depends on specific characteristics of demand, i.e. (i) for whom (e.g. age groups), (ii) during what time of the day (e.g. prime time), and (iii) for what purposes (e.g. genre, motivation/intention). In order to tackle our research questions, we empirically analyze the audiovisual viewing patters by employing an econometric analysis based on a quantitative online survey in Germany. With a unique dataset of almost 3,000 participants, we are able to provide differentiated results on age groups, choices through different times of day and consumption differences regarding genres and intentions. The rich data set provides wide information on stated and pseudo- 
revealed preferences ${ }^{3}$ of respondents, i.e. direct answers stating the respondent's opinion and preferences in agreement with self-perception versus indirect questions revealing preferences and ideas the respondent might not directly be aware of. We are able to show that those preferences diverge. While consumers state that YouTube-style AVoD does not represent an alternative to Netflix-style PVoD for them, the consumption habits described by the respondents indicate the opposite for prime time consumption. In general, the results support that consumers with limited time capacities need to decide between competing ways to get entertained. Especially the decision of evening and prime time entertainment is not trivial and shows that consumers do not clearly prefer one distinctive medium, displaying a strong competitive relation. In contrast, consumption of specific genres, for instance, sports or news hints at less competitive relations.

The paper is organized as follows: section 2 summarizes the pro and contra reasons for these different audiovisual online streaming services being alternatives for users. Then, section 3 presents our survey data and the empirical analysis. Based upon the results, section 4 discusses implications and section 5 concludes.

\section{Audiovisual Markets and Competition}

The ongoing process of digitization and the spread of broadband internet technology considerably increased the option for consumers to watch moving audiovisual contents. Traditional television - irrespective of its transmission media (terrestrial, cable, satellite, online, etc.) - now facing video-on-demand services changes the competitive landscape. This may be good news since in many national television markets (including Germany), concentration and (a lack of) competition have been continuous concerns (Budzinski \& Wacker 2007; Bundeskartellamt 2011a,b, 2015; OFCOM 2018). However, the competitive interrelations between TV and VoD as well as among different types of VoD services are subject to controversial discus-

3 Please note, since these answers are not revealed preferences of actual consumption behavior, but descriptions on their behavior by the respondents, we consider them as pseudo-revealed. For a discussion of stated and revealed preferences in online media from an economic perspective, see Budzinski \& Kuchinke (2020). 
$\operatorname{sion}^{4}$ - and as mentioned in section 1, most empirical studies ignore YouTube when they discuss VoD markets.

Although on first sight all types of services provide audiovisual contents and, thus, serve the same needs of the consumers, a number of issues are raised that may limit the intensity of competition between them.

- An often-raised objection claims a service like YouTube (AVoD) does not compete with the likes of traditional TV and PVoDs like Netflix because its content is predominantly non-professional and/or non-commercial (inter alia, Bruns 2008; Ritzer \& Jurgenson 2010; Bundeskartellamt 2011a, 2015; Dennhardt 2014; Fuchs 2014). According to this view, YouTube mainly represents a social media platform where users upload content for other users (cat videos, fail videos, etc.), i.e. a sort of user-exchange of contents, and professional contents from business companies are in the clear minority. The nature of YouTube's early 'user generated content' (from users for users) has changed a lot and initial 'private' uploaders professionalized towards being active content providers, offering regular video uploads regarding specific topics according to the channels media concept (Döring 2014; Budzinski \& Gaenss/e 2018). Notwithstanding the still existing type of non-professional content, this trend of professionalization points towards the significant turnovers and revenues that content providers like so-called social media stars ${ }^{5}$ earn through participation on YouTube's advertisement revenues as well as through product placements - with the latter further emphasizing the commercial nature of the content supply (Budzinski \& Gaenssle 2018; Gaenssle \& Budzinski 2020). Nowadays, a significant share, if not most of the views on YouTube, fall on commercial content, most of which is professionally produced; the most popular 20 percent receive 97 percent of views (Ding et al. 2011) and 10-30 percent of videos have fewer than ten views (Chowdhury \& Makaroff 2013).

Less than a decade ago, the Federal Cartel Office of Germany (Bundeskartellamt) denied the existence of relevant competitive pressure from YouTube on German television channels (Bundeskartellamt 2011a,b, 2015; Budzinski \& Lindstädt-Dreusicke 2020).

5 Social media stars (so-called: influencers, creators, micro-celebrities, online stars, etc.) are successful content providers on social media platforms like YouTube or Instagram (for a detailed analysis see Gaenssle \& Budzinski 2020). 
- Content differences between the different types of services represent a second aspect. While YouTube is known to predominantly provide shorter videos (e.g. short clips, music videos \& social media star entertainment), both Netflix and TV focus on longer pieces like movies, series and shows. The content differences may go along with different ways of consumption. For quick information (specific tutorials/help, etc.) or social network elements (i.e. follow stars or friends, sharing content), YouTube meets the consumers' preferences, whereas for full-length video content the choice falls on the other types of services. Therefore, YouTube may be more relevant for purposes like bypassing waiting or travelling times, covering smaller breaks and shorter entertainment spaces, etc., whereas PVoDs like Netflix and TV are preferred for filling an evening of entertainment or a free Sunday afternoon, for instance. As such, the services would rather complement each other than compete with each other. These differences in contents and consumption could reflect in service usages different times of day: Netflix and TV should be the prime-time competitors according to this view, whereas YouTube is more a media for "in-between" moments throughout the rest of the day. However, with the professionalization of AVoD content, average video length is developing towards traditional video formats. A study conducted by the search engine Pex (Turek 2019) shows that average YouTube videos are $11.7 \mathrm{~min}$ long (December 2018), with popular categories reaching up to $25 \mathrm{~min}$ on average (gaming $24.7 \mathrm{~min}$; film \& animation $19.2 \mathrm{~min}$ ). Moreover, serial consumption of videos and so-called binge watching (Rubenking et al. 2018; Gaenssle \& Kunz-Kaltenhäuser 2020) allows consumers to watch hours of video content without interruption - a phenomenon that is further fueled by individualized recommendation systems and auto-play modes. ${ }^{6}$ Independent of the single video length, this may result in hours of successive consumption; accumulating to a total consumption length, which is easily comparable to full-length movies. These developments show converging trends and increasing comparability of services.

6 The platform Twitch (twitch.tv), for instance, allows content providers 24 hours streaming. 
- A further difference may relate to the device of usage. One expects consumers of traditional television programs or Netflix (PVoD) to prefer large television screens, while YouTube-style AVoD services are mostly watched on mobile devices (laptops, tablets and, particularly, smartphones). However, due to the possibility of downloading content to mobile devices and watching it 'on the road', consumers may start to watch their favorite shows - regardless of the original service (AVoD, PVoD or TV) - while e.g. traveling to work.

- Eventually, social networking elements like commenting, sharing or liking content may represent a differentiator. This social media function is usually not possible for linear TV, although broadcasters recently started to increase audience engagement e.g. in live shows with audience questions or the possibility of writing (WhatsApp) messages. Nevertheless, due to the nature of the non-linear availability of content, audience ratings, comments, and shares are possible on AVoD and PVoD. Especially AVoD pages like YouTube or Twitch have networking elements and very active 'below video commenting behavior'. However, former non-digital players in the market also adapt to new possibilities and try to increase audience engagement.

Overall, the different services seem to converge and try to use all possible ways to increase the time recipients spent consuming their content. Attention may be a scarce resource and, in the face of information overflow due to omnipresent mobile access to the internet, a relevant one for online content consumption (Falkinger 2008; Evans 2013; Boik et al. 2017). According to the economics of attention, all content providers compete for the scarce attention of the users who can spend every minute of their attention only once. Therefore, if a user opts for watching YouTube videos, she cannot spend this attention to a Netflix serial anymore and vice versa (opportunity costs). Given that many users spend a relevant time of any day for working, sleeping, and other activities (childcare, sports, etc.), competition for the remaining time for watching audiovisual online content may be intense. Furthermore, even though there are differences in detail, a large part of content and consumption regarding all three types of services is about entertainment and, thus, referring to the same underlying intention or want of the consumer. 
While the reasoning so far has focused on possible differences between YouTube on the one side and both TV and Netflix-style services on the other side, the case for the latter two being in competition with each other appears to be more straightforward. In a way, services like Netflix may be viewed to be the "new TV", entailing the advantages of traditional TV and adding the luxury to be non-linear, so that users do not depend on a given program schedule anymore but can cherry pick their times and contents. Therefore, it may mainly be a generation effect separating the two types of services with older generations just being slower to adapt to a superior new good.

However, while enhanced choice options will mostly benefit consumers' preferences, there can be exceptions to that. Choosing does require investing cognitive capacity and in some situations in life - like the end of an exhausting day where someone just looks for some relaxing entertainment before going to sleep or background entertainment without active engagement (like radio consumption is often done) - users may not want to spend these resources. Then, a linear service like TV may be superior. Linear TV programming demands, thus, less cognitive engagement and decisiveness. Moreover, regular television consumers might enjoy the feeling of being connected to society, watching what other people nationwide are also watching, i.e. networking and commonality effects as well as cultural inclusion by e.g. national popular TV shows. And finally, the bundling of information and entertainment, e.g. news and prime-time movie as a bundle, may be valued by consumers, and be very tiresome to self-compile (or even impossible due to lack of supply) on PVoD and AVoD.

The algorithm-based recommendation service of Netflix and co. may substitute for the linear program schedule in such cases. Based on individual data, recommender systems provide content suggestions for (indecisive) consumers. To simplify the demand-process and lower the cost of active consumption decisions, services use auto-play modes (immediately starting the next video), content suggestions, trailers, etc.

Altogether, the theoretical reasoning does not yield a clear picture and, therefore, emphasizes the relevance of an empirical analysis. This empirical analysis must con- 
sider that the intensity of competition may vary with factors like age, intention, genre, or time of day.

\section{Empirical Analysis of Audiovisual Media Consumption}

\subsection{Methodology and Data}

\subsubsection{Sampling and Data}

The data used for the empirical analysis originates from an online survey conducted from November 2018 until February 2019 in Germany (by Ilmenau University of Technology and the Business School at Pforzheim University). It is an academically motivated study, independent of external funding or other heteronomous interests. The standardized quantitative online questionnaire was specifically designed to match the research questions mentioned above. We attracted 3,882 registered visits, of whom 3,277 started the questionnaire, to eventually reach $N=2,920$ valid finishers. The students, who were responsible for the sampling, executed the recruitment and invitations to the questionnaire, i.e. spreading it mainly among their peers (young people and older relatives). The survey participation was predominantly voluntarily, although driven by social obligations towards the students conducting it. At Pforzheim University 'StudiQUEST' a panel of students and alumni was involved. Moreover, the invitation to the questionnaire was placed at the landing page of 'serienjunkies.de' for a week in January 2019. All parts of Germany are represented within the sample; however, the states of origin are over-represented (with 650 from Ilmenau and surrounding, and 661 from Pforzheim and surrounding). The average age of respondents is 31.55 years (min: 10; $\max : 83$ ); with 48.15 percent male, 50.65 percent female, 1.2 percent 'other'. Since the survey was conducted in a university environment, the sample is biased towards a young, highly educated, low-income group; 56.4 percent have an income lower than EUR 1,500. ${ }^{7}$ The educational level is displayed in table 1 and shows that 29.62 percent have a university entrance qualification and $\mathbf{4 2 . 5}$ percent a university degree.

7 See appendix 1 and 2 for detailed information on income and age groups. 
Table 1: Educational Level Sample

\begin{tabular}{|l|l|l|l|}
\hline International Education Status & Freq. & Percent & Cum. \\
\hline \hline without educational degree & 10 & 0.34 & 0.34 \\
\hline secondary school degree & 211 & 7.23 & 7.57 \\
\hline university entrance qualification & 865 & 29.62 & 37.19 \\
\hline Apprenticeship & 477 & 16.34 & 53.53 \\
\hline university degree & 1,241 & 42.50 & 96.03 \\
\hline PhD & 78 & 2.67 & 98.70 \\
\hline no response & 38 & 1.30 & 100.00 \\
\hline \hline Total & 2,920 & 100.00 & \\
\hline
\end{tabular}

The representativeness of the sample cannot be guaranteed for all relevant aspects of the analysis and cannot be compared to well-structured cluster sampling. Notwithstanding, given the sample size, we find both variance and randomness to meet statistical requirements. It provides information on stated and pseudorevealed preferences of the participants and if/how, they diverge. Moreover, the over-sampling within young age groups can be used in favor of the analysis, as especially young adults use VoD offers. ${ }^{8}$ For the analysis of competition between online services more information on consumers, who know and actually use all services, is very valuable. These trends will intensify over time with growing numbers of young generations and changing consumption habits.

\subsubsection{Data Analysis and Variables}

The questionnaire comprises of 13 content-related separate questions (excluding demographic questions, like age, gender, etc.), two of which ask for the frequency of media usage (different services and devices). To answer our research questions, the consumption of video content via the different services is crucial. Which service is used at what time and how much content is consumed? The frequency (i.e. how often consumers use the service) and the duration (i.e. how much time they spend consuming video content) are relevant to analyze the extent of usage and im-

8 See section 1 as well as Kupferschmitt (2018) for Germany, Statista (2018) for the US, and Lindstädt-Dreusicke \& Budzinski (2020) for a supportive economic analysis. 
portance of the respective service. Therefore, we are interested in the consumption intensity depending on the respective type of media service $i=\{A V o D ; P V o D ; T V\}$ and construct a pseudo-metric dependent variable for the analytical analysis:

(1) Consumption Intensity $y_{i}=$ Frequency $_{i} \cdot$ Duration $_{i}$

(2) $Y_{i} \triangleq$ Consumption Intensity $y_{i}$

If services compete for the consumer's attention, it is a question of time allocation. The intensity of usage represents the time spend on consumption, as pictured in figure 1, the consumer can either spent more time within one sitting (B) or shorter sittings with higher frequency (A). The exposure to content and time allocated to consumption is the same in both cases.

\section{Figure 1: Consumption Intensity of Service i}

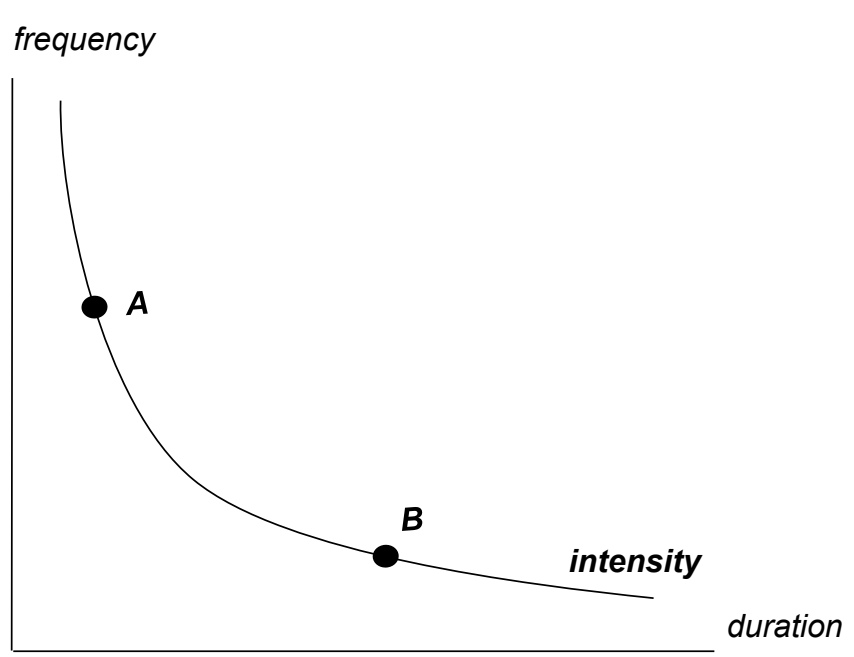

The frequency of usage is measured on a seven-point scale from high to low frequency ( 6 = several times daily; $0=$ never) for each service, supplemented by the option 'no response'. The duration of video consumption in one sitting, i.e. how long without taking a break or switching activity, was also measured for each service separately. By moving a regulator on a scale from ' 0 ' to ' $>3 \mathrm{~h}$ ' (in seven steps), the respondents could state the length of one average sitting. The multiplication of the variables gives us a range of 25 points $(0=$ never, $24=$ several times daily, more than three hours). The intensity of the usage can thus be expressed by the new dependent variable on a range from non-users (never), over medium-users 
(e.g. monthly, on average one hour) to heavy-users (several times daily, more than three hours).

Four independent variables are used for the analysis: (1) intention of usage (entertainment, shorten waiting time, stimulate knowledge, personal motivation (i.e. career/health)), (2) genre (feature film, documentary, series, tutorial, sports, news, comedy, music videos), (3) time of day (of service $i$; noon, afternoon, evening $\left.{ }^{9}\right),(4)$ information on individuals $j$ (age category, gender, education).

Since we are not only interested in the factors explaining the intensity of consumption, but the interaction between the different services, i.e. competitive relations between YouTube, Netflix and TV, we decide to perform a seemingly unrelated regression estimation (SURE) (Zellner 1962; Zellner \& Huang 1962; Zellner 1963). This method is commonly used for supply and demand models. Our model consists of three regression estimations, each with its own dependent variable (for the respective services $i$ ). While every equation can be seen as an independent linear regression and can be estimated separately, error terms are expected to be correlated across equations. As such, it is a system of linear equations with error terms that are correlated across equations for a given individual but not across individuals. When the models do not have the same set of independent variables and error terms are correlated, SURE can lead to more efficient results than separate OLS (ordinary least square) estimations. Moreover, it is suitable to perform joint tests.

The model consists of $i=\{A V o D ; P V o D ; T V\}$ linear regression equations for $j=1 \ldots N$ individuals. The $i$ th equation for individual $j$ is

$$
\text { (3) } Y_{j i}=x_{j i}^{r} \beta_{i}+u_{j i}
$$

Stacking all observations, the model for the $i$ th equation is

$$
\text { (4) } Y_{i}=x_{i}^{\prime} \beta_{i}+u_{i}
$$

Multiple answers were possible. We excluded "morning" and "night" due to multi-collinearity. Moreover, these periods do not add more information on competitive relations from a theoretical point of view (see figure 5 for an overview between daytimes). 
Here, the error terms $u$ are allowed to be correlated to estimate a full variancecovariance matrix of coefficients.

In addition to the econometric analysis, we use direct questions to show stated preferences in descriptive statistics (see 3.2.1). Two questions in the survey feature item batteries (six items each) of attitude measurement with five-point Likert scales ( 1 = disagree to 5 = agree; $6=$ no response). In accordance with findings of Revilla et al. (2014), who found that five-point scales are statistically equivalent (in terms of validity and efficiency) to seven-point or larger scales, we find five-points scales intuitive for respondents and analysis.

\subsection{Results and Discussion}

\subsubsection{Descriptive Statistics and Results}

To understand the motives of consumers and their personal perception, we directly ask them on their agreement on a five-point Likert scale (description see 3.1.2). Among the questions of (dis-)agreement, we asked if respondents agreed that (i) YouTube (AVoD) is an alternative to Netflix (PVoD), (ii) Netflix (PVoD) is an alternative to TV, and (iii) YouTube (AVoD) is an alternative to Netflix (PVoD). In doing so, consumers are directly asked for their opinion and state their preferences for video consumption. A detailed presentation of answers within the different age groups reveals interesting results.

(i) The answers to the question whether YouTube-style AVoD is an alternative for TV are rather dichotomous. In total 38.59 percent tend to disagree, 12.71 percent are neutral, and 48.05 percent tend to agree $(0.65$ percent 'no response'). Looking at the age groups the difference is apparent with 38.89 percent of people older than 60 years strongly disagreeing and 49.04 percent younger than 19 years strongly agreeing (figure 2). The results show deep differences between far end age groups and their consumption behavior. 


\section{Figure 2: AVoD-TV Alternatives}

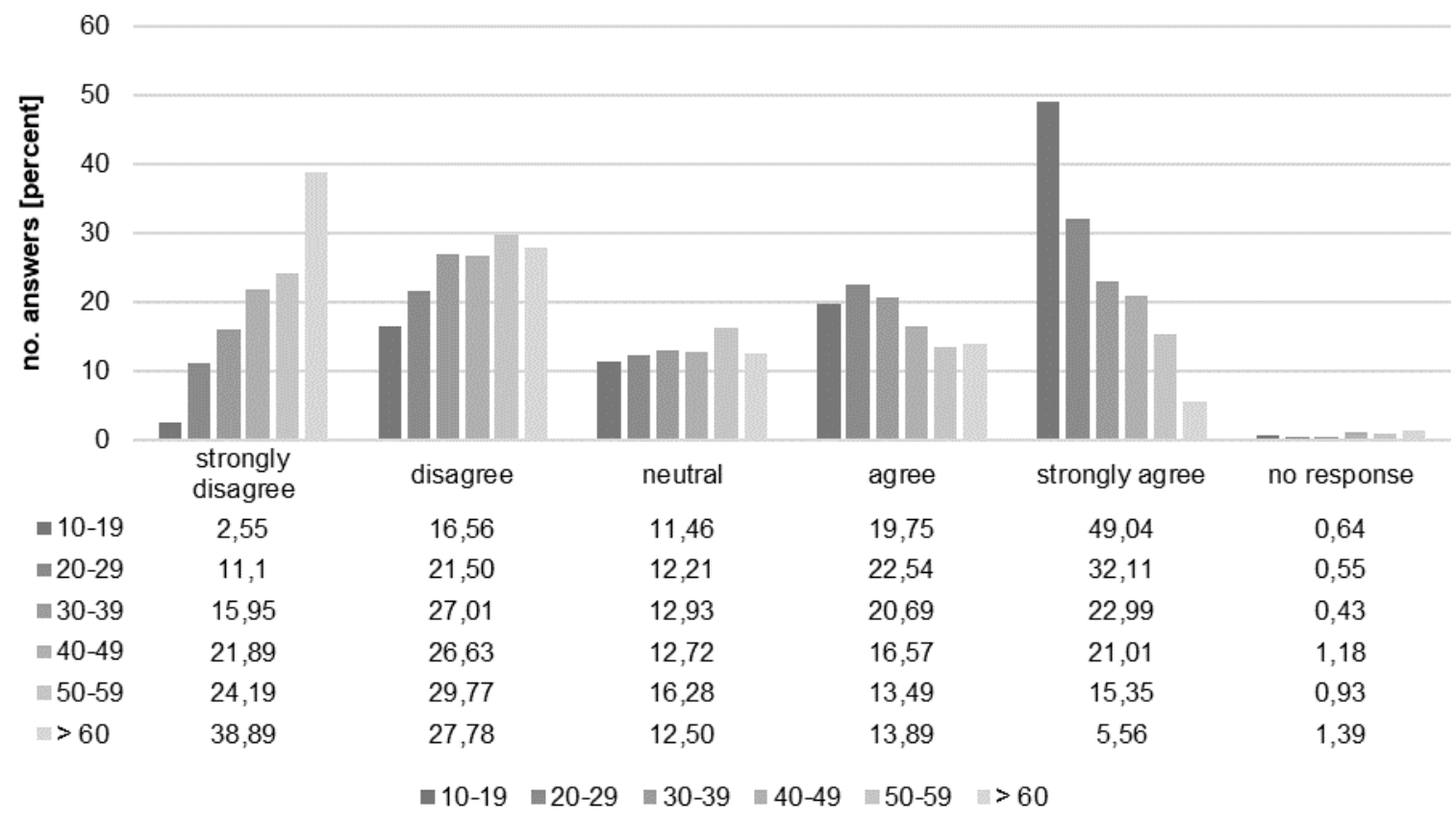

(ii) When it comes to Netflix-style PVoD versus TV, the answers are much more homogenous, since most consumers in our sample tend to perceive them as close alternatives and strongly agree (figure 3). Again, only those older than 60 years express a strong opinion against PVoD being an alternative to TV.

\section{Figure 3: PVoD-TV Alternatives}

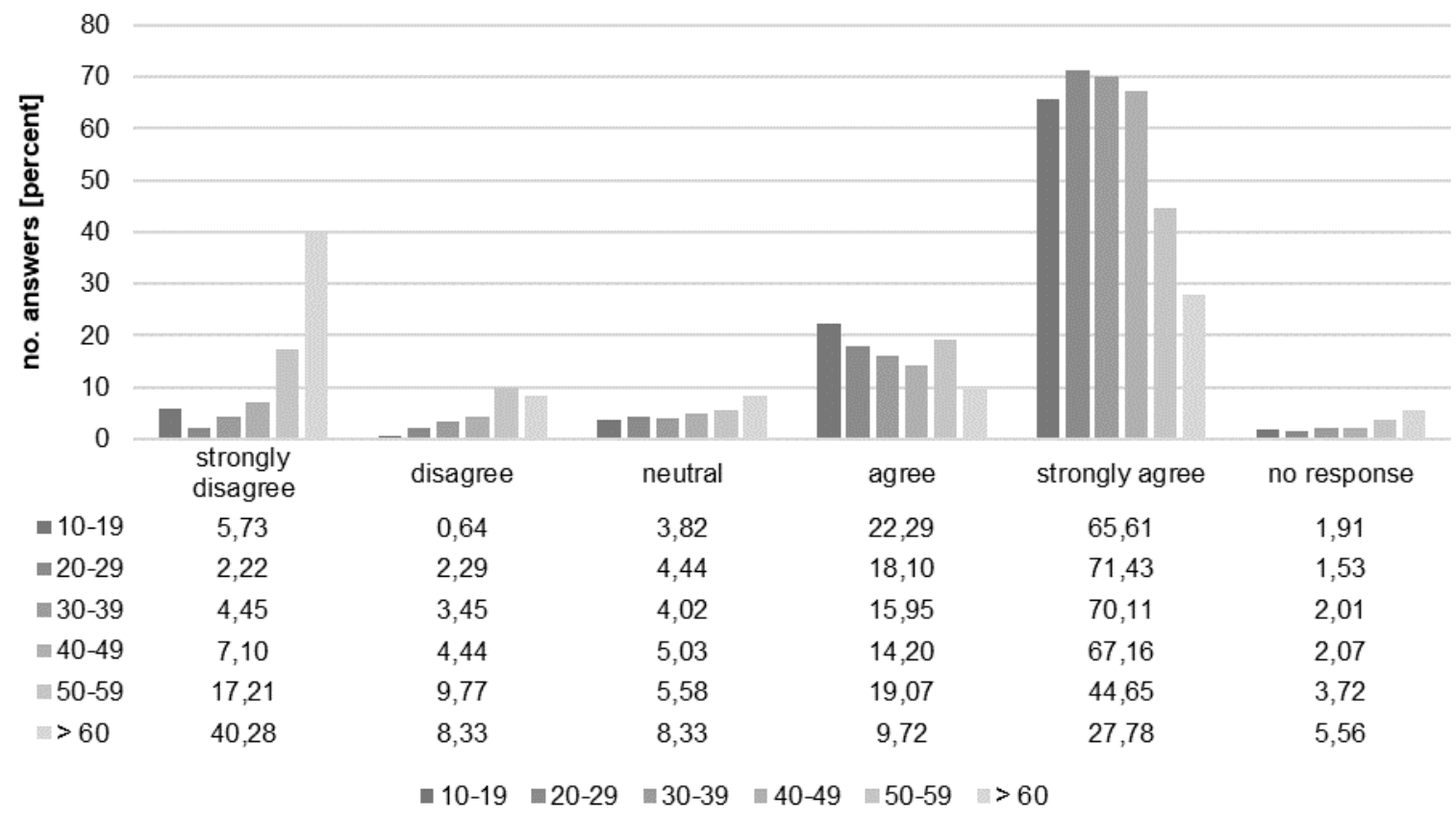


(iii) Lastly, the relationship between YouTube-style AVoD and Netflix-style PVoD is shown in figure 4 . There is no considerable difference between age groups and the results are comparatively heterogeneous. In total more respondents seem to disagree with $\mathrm{AVoD}$ and PVoD serving a similar purpose; 58 percent disagreement, 15.55 percent neutral, 22.91 percent agreement (7.74 percent of which strongly), and 3.46 percent 'no response'. Thus, in our sample, considerably fewer people think of YouTube as an alternative to watching Netflix (about 23 percent) than to watching TV (about 48 percent). Still, it is quite surprising that almost 23 percent of respondents within the sample agree to $A V O D$ and PVoD being alternatives for one another.

Figure 4: AVoD-PVoD Alternatives

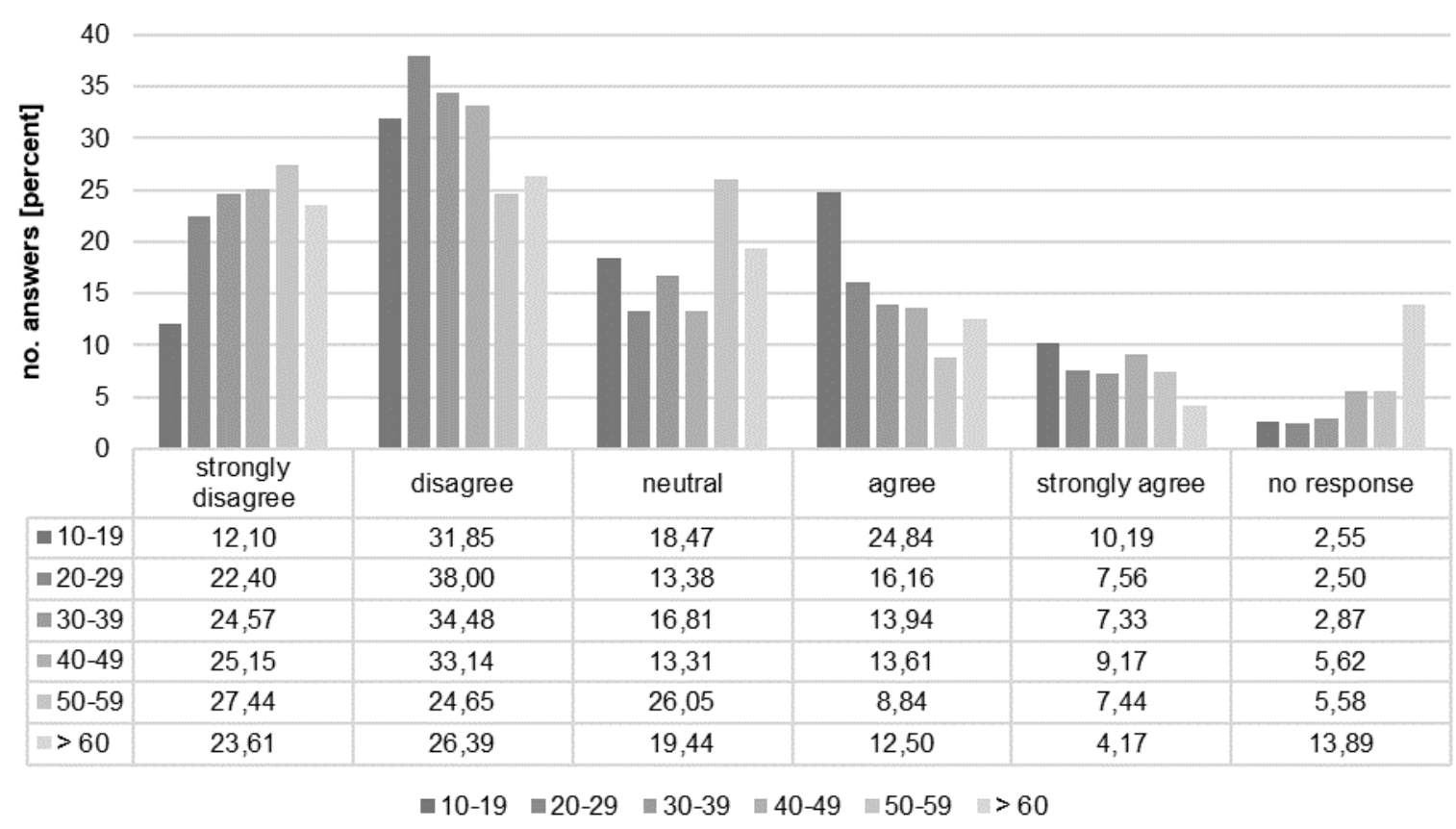

Switching from how the respondents assessed the different services when directly asked to the more detailed self-description of their consumption behavior reveals interesting patterns. Most consumers spend their evening time to consume video content, apparently actively choosing between the respective services. Figure 5 displays daytimes and total number of respondents using the service at that time (multiple answers possible). Note that $n=2,920$. In other words, more than 70 percent of the respondents in our sample indicate that they use all three services 
(YouTube, Netflix, TV) for evening video consumption. Therefore, while consumers consider the services to be different, they still choose between them as alternatives to consume audiovisual contents in the evening. Consequently, AVoD, PVoD and TV seem to compete for the consumers' attention during peak times of consumption and standard leisure time (prime time entertainment), whereas things look different at other times of day.

\section{Figure 5: Daytime Usage}

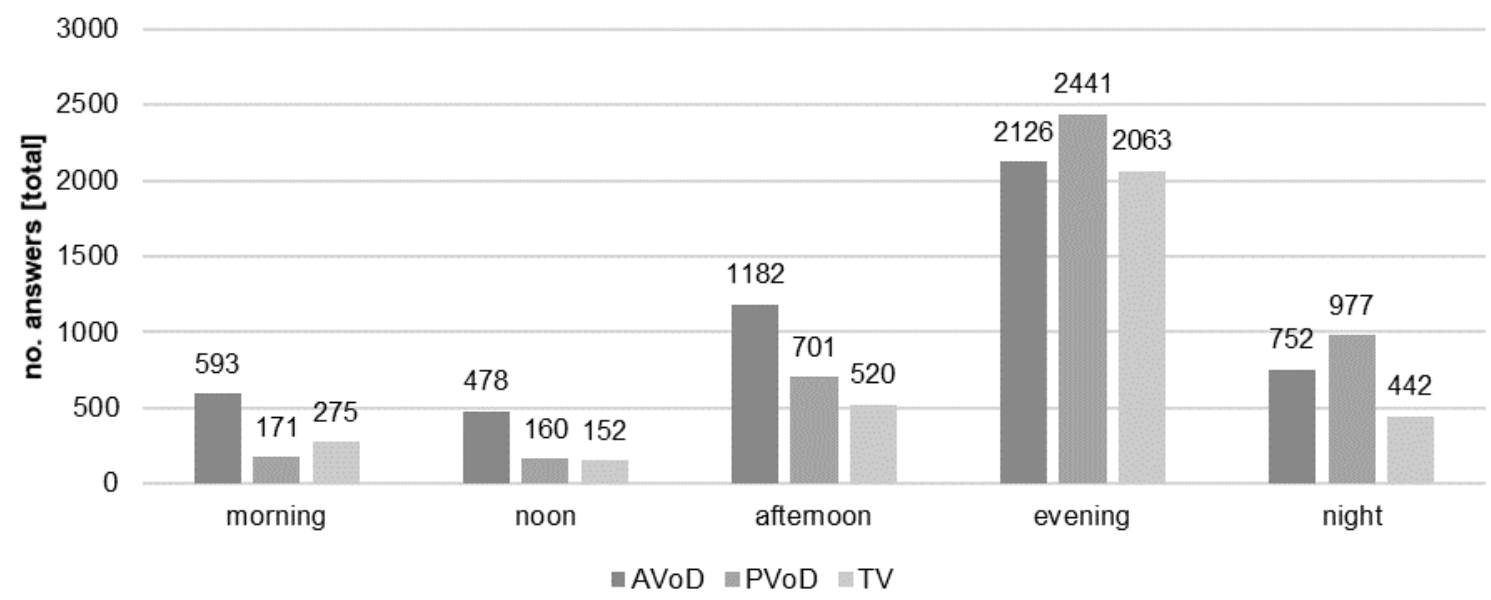

Summing up, the descriptive results show that there is no strict line between the different services, although most consumers agree to PVoD being an alternative for TV. Among younger generations AVoD seems to be a better alternative to TV than for older generations. The results for PVoD and AVoD are mixed. Consumers state to use the services for different reasons, yet, when it comes to the time they spend on consumption, the services seem to be in close competition for the consumers attention during prime time in the evening (but not at other times during the day). Altogether, the descriptive results are not fully conclusive. A detailed analysis with more sophisticated methods is necessary to verify the results.

\subsubsection{Econometric Analysis and Results}

By the means of seemingly unrelated regression estimations (see 3.1.2 for details on the SURE model), we analyze the influence of different intentions, genres, times of day, and individual characteristics (age, education, gender) on consumption intensity of (1) AVoD, (2) PVoD, and (3) TV. Table 2 displays the results for one mod- 
el, the three different dependent variables (1-3) in the columns next to each other. ${ }^{10}$ Due to filter questions, only $N=2,333$ observations are taken into account.

Table 2: Results AVoD, PVoD \& TV

\begin{tabular}{|c|c|c|c|}
\hline & (1) & $(2)$ & (3) \\
\hline VARIABLES & AVoD & PVoD & TV \\
\hline \multirow{2}{*}{ Intention: Entertainment } & 0.033 & -2.852 & -2.396 \\
\hline & $(1.960)$ & $(1.760)$ & $(2.451)$ \\
\hline \multirow[t]{2}{*}{ Intention: Shorten Waiting Time } & 0.093 & $0.709 * * *$ & 0.249 \\
\hline & $(0.250)$ & $(0.225)$ & $(0.314)$ \\
\hline \multirow[t]{2}{*}{ Intention: Stimulate Knowledge } & $1.157^{* * *}$ & $-0.425^{*}$ & $-0.915^{* * *}$ \\
\hline & $(0.271)$ & $(0.243)$ & $(0.340)$ \\
\hline \multirow[t]{2}{*}{ Intention: Personal Motivation } & $1.549 * * *$ & -0.217 & $-1.170 * * *$ \\
\hline & $(0.297)$ & $(0.268)$ & $(0.373)$ \\
\hline \multirow[t]{2}{*}{ Genre: Feature Films } & -0.346 & $2.226^{* * *}$ & $1.614^{* *}$ \\
\hline & $(0.529)$ & $(0.473)$ & $(0.662)$ \\
\hline \multirow[t]{2}{*}{ Genre: Documentary } & 0.077 & 0.074 & -0.355 \\
\hline & $(0.314)$ & $(0.282)$ & $(0.393)$ \\
\hline \multirow[t]{2}{*}{ Genre: Series } & 0.965 & $5.539 * * *$ & -1.055 \\
\hline & $(0.626)$ & $(0.560)$ & $(0.782)$ \\
\hline \multirow[t]{2}{*}{ Genre: Tutorials } & -0.354 & 0.047 & -0.389 \\
\hline & $(0.264)$ & $(0.237)$ & $(0.331)$ \\
\hline \multirow[t]{2}{*}{ Genre: Sports } & $-0.662 * * *$ & 0.173 & $1.990 * * *$ \\
\hline & $(0.257)$ & $(0.230)$ & $(0.319)$ \\
\hline \multirow[t]{2}{*}{ Genre: News } & $-0.659 * *$ & -0.324 & $2.160 * * *$ \\
\hline & $(0.289)$ & $(0.259)$ & $(0.360)$ \\
\hline \multirow[t]{2}{*}{ Genre: Comedy } & $0.862^{* * *}$ & 0.327 & 0.056 \\
\hline & $(0.265)$ & $(0.237)$ & $(0.332)$ \\
\hline \multirow[t]{2}{*}{ Genre: Music Videos } & $0.915^{* * *}$ & 0.207 & -0.166 \\
\hline & $(0.259)$ & $(0.233)$ & $(0.325)$ \\
\hline \multirow[t]{2}{*}{ Time of Day AVoD Noon } & & 0.423 & -0.229 \\
\hline & & $(0.306)$ & $(0.431)$ \\
\hline \multirow[t]{2}{*}{ Time of Day AVoD Afternoon } & & -0.098 & -0.060 \\
\hline & & $(0.231)$ & $(0.332)$ \\
\hline \multirow[t]{2}{*}{ Time of Day AVoD Evening } & & $-1.169 * * *$ & 0.061 \\
\hline & & $(0.250)$ & $(0.351)$ \\
\hline \multirow[t]{2}{*}{ Time of Day PVoD Noon } & -0.366 & & -0.013 \\
\hline & $(0.537)$ & & $(0.676)$ \\
\hline \multirow[t]{2}{*}{ Time of Day PVoD Afternoon } & $0.828 * * *$ & & 0.279 \\
\hline & $(0.296)$ & & $(0.368)$ \\
\hline
\end{tabular}

10 We performed regression specification tests on separate OLS regressions (each dependent variable separately) to check the applicability. Especially multi-collinearity was of concern, but the variance inflation factors (VIFs) for the independent variables show values below five for each linear regression. Moreover, we checked if all equations together are statistically significant. The Breusch-Pagan test of independence shows that, for the same individuals, the correlation of the residuals is significant and we can reject the hypothesis that this correlation is zero. 


\begin{tabular}{|c|c|c|c|}
\hline \multirow[t]{2}{*}{ Time of Day PVoD Evening } & \multicolumn{2}{|l|}{$-1.105^{* *}$} & \multirow{2}{*}{$\begin{array}{l}-0.702 \\
(0.667)\end{array}$} \\
\hline & $(0.531)$ & & \\
\hline \multirow[t]{2}{*}{ Time of Day TV Noon } & 0.026 & -0.137 & \\
\hline & $(0.544)$ & $(0.485)$ & \\
\hline \multirow[t]{2}{*}{ Time of Day TV Afternoon } & -0.375 & 0.114 & \\
\hline & $(0.331)$ & $(0.286)$ & \\
\hline \multirow[t]{2}{*}{ Time of Day TV Evening } & $-1.750 * * *$ & $-1.366 * * *$ & \\
\hline & $(0.284)$ & $(0.255)$ & \\
\hline \multirow[t]{2}{*}{ Age Categories $=2,20-29$} & $-1.858 * * *$ & 0.009 & -0.687 \\
\hline & $(0.552)$ & $(0.498)$ & $(0.695)$ \\
\hline \multirow[t]{2}{*}{ Age Categories $=3,30-39$} & $-3.033^{* * *}$ & 0.427 & 1.037 \\
\hline & $(0.600)$ & $(0.542)$ & $(0.757)$ \\
\hline \multirow[t]{2}{*}{ Age Categories $=4,40-49$} & $-4.346^{* * *}$ & 0.526 & $2.754 * * *$ \\
\hline & $(0.660)$ & $(0.596)$ & $(0.832)$ \\
\hline \multirow[t]{2}{*}{ Age Categories $=5,50-59$} & $-4.585^{* * *}$ & -0.844 & $4.342 * * *$ \\
\hline & $(0.736)$ & $(0.665)$ & $(0.926)$ \\
\hline \multirow[t]{2}{*}{ Age Categories $=6,>60$} & $-5.145^{* * *}$ & $-2.128^{*}$ & $4.611 * * *$ \\
\hline & $(1.216)$ & $(1.095)$ & $(1.534)$ \\
\hline \multirow[t]{2}{*}{ Gender $=1$, female } & $-2.610 * * *$ & $-0.568^{* *}$ & $1.879 * * *$ \\
\hline & $(0.264)$ & $(0.239)$ & $(0.333)$ \\
\hline \multirow[t]{2}{*}{ Gender $=2$, other } & 0.381 & 0.256 & -0.318 \\
\hline & $(1.213)$ & $(1.089)$ & $(1.521)$ \\
\hline \multirow[t]{2}{*}{ International Education Status $=2$, secondary school degree } & -2.295 & 0.240 & 0.732 \\
\hline & $(2.437)$ & $(2.185)$ & $(3.054)$ \\
\hline \multirow[t]{2}{*}{ International Education Status $=3$, university entrance qualification } & -2.824 & -0.356 & -1.080 \\
\hline & $(2.408)$ & $(2.159)$ & (3.019) \\
\hline \multirow[t]{2}{*}{ International Education Status $=4$, apprenticeship } & -3.609 & 0.661 & -0.058 \\
\hline & $(2.424)$ & $(2.174)$ & $(3.040)$ \\
\hline \multirow[t]{2}{*}{ International Education Status $=5$, university degree } & $-4.411 *$ & -0.646 & -1.032 \\
\hline & $(2.411)$ & $(2.163)$ & $(3.023)$ \\
\hline \multirow[t]{2}{*}{ International Education Status $=6, \mathrm{PhD}$} & $-5.430 * *$ & -2.079 & 0.091 \\
\hline & $(2.568)$ & $(2.302)$ & $(3.218)$ \\
\hline \multirow[t]{2}{*}{ International Education Status $=7$, no response } & $-4.467^{*}$ & -0.004 & 0.084 \\
\hline & $(2.624)$ & $(2.352)$ & $(3.287)$ \\
\hline \multirow[t]{2}{*}{ Constant } & $17.901^{* * *}$ & $13.694^{* * *}$ & $10.746^{* * *}$ \\
\hline & $(3.163)$ & $(2.809)$ & (3.959) \\
\hline Observations & 2,333 & 2,333 & 2,333 \\
\hline R-squared & 0.177 & 0.111 & 0.099 \\
\hline
\end{tabular}

Standard errors in parentheses

*** $p<0.01,{ }^{* *} p<0.05,{ }^{*} p<0.1$

Results intention: We asked for the different intentions consumers have for watching video content. While getting entertained is one of the main intentions, the results are not significant in our model, approximately due to lack of variance in the answers. However, other results show significant coefficients. At the first glance 
surprisingly, 'shorten waiting time' is significantly positive for Netflix-style PVoD, while it is not for YouTube-style AVoD. This appears to be counterintuitive because based on the theoretical reasoning (see section 2), one would expect a lot of mobile and 'on the road' usage of YouTube-style services. Yet, an explanation could be that many users download videos from Netflix or Amazon and watch them while traveling on the bus/train etc. Mobile internet connection in Germany is often limited (Briglauer et al. 2019), so traveling to work or long distances might lead through "dead spots" without sufficient signal strength. Regarding 'stimulating knowledge', research and learning are closely connected to YouTube usage, which can explain the positive results for 'stimulating knowledge' on AVoD. In that regard, PVoD and TV do not seem to compete with YouTube \& Co, as the results for those services are significantly negative. The same is true for 'motivation' and TV. Consumers who seek motivation (e.g., health or career) use YouTube-like services, whereas the coefficient for TV is negative regarding this aspect.

Results genre: 'Feature films' are significantly positive for the intensity of usage of both Netflix and TV. Therefore, it can be expected that the services compete for consumer attention, when they are choosing full-length feature films. However, the preferences for 'series' on Netflix-style PVoD are obvious. 'Sports' are significantly negative on AVoD, whereas significantly positive on TV, which could be due to lack of supply on YouTube \& Co rather than lack of demand. This is similar to 'news' and the opposite direction to 'music videos'. A discussion of the issue of limited supply of one genre on certain services is provided in section 4. 'Comedy' is positive for YouTube-style AVoD consumption intensity. While comedy can also be found in traditional television and on PVoD, participants in our study seem to prefer AVoD channels.

Time of day: Interestingly, and in accordance with descriptive results, there seems to be intensive competition for prime time consumption. When asking the participants about the time of consumption during the day, multiple answers for the different services were possible. There are no significant results for the time around noon. On the one hand, the preference to watch PVoD in the afternoon increases the probability of $A V O D$ consumption intensity. On the other hand, in the evening the PVoD consumption has negative impact on AVoD consumption. The other way 
around, AVoD evening preferences negatively influence PVoD consumption. Moreover, prime time television choices negatively affect both AVoD and PVoD. These analytical results confirm the descriptive results in chapter 3.2.1 and show that services compete for the consumers' attention - despite differing contents. If consumers simply want to get entertained, they seem to choose among all of the three services in their free time (primarily prime time in the evening).

Results age categories: The base group for age is $10-19$ years. The negative coefficients show that all older age groups use relatively less YouTube-style AVoD, which thus is the "youngest" service among the three. There are no statistically significant results for Netflix-style PVoD, except for the group older than 60 years, who generally do not prefer to watch VoD services. TV shows opposing effects, since expectably older age groups tend to watch more television than younger ones. Thus, our results match other, more representative studies (summarized in section 1) with respect to generation effects, increasing confidence in the results of our study which is not that representative but digs deeper into the topic.

In summary, the results of the empirical analysis show that (i) services compete for prime time attention of consumers, supporting the descriptive findings (see 3.2.1); (ii) show that 'intention' and preferred 'genre' mostly vary between services, yet, consumers like to get entertained by all of them, ${ }^{11}$ and (iii) concerning age groups, younger people actively choose AVoD channels, supporting the results of more representative studies. In the light of the ongoing dynamic development of online VoD service-offerings, competition between services seems likely to increase in the course of time.

\section{Summary and Limitations}

Theoretical reasoning suggests that types of services that are more similar to each other should stand in closer competition than more dissimilar services (see section 2). Given the state of the German market at the time of the survey, this would imply to expect that content-wise TV and PVoD à la Netflix are close competitors. Whereas YouTube as the main AVoD outlet is less of an alternative to TV, with the

112,893 out of 2,920 participants choose at least one of the services to get entertained. 
AVoD-PVoD interrelation maybe to be expected somewhere in-between as they share the non-linear character despite of content differences. Some results of the econometric analysis in fact show limited competition between YouTube and TV, e.g. the intention to stimulate knowledge, or finding personal motivation in video content. In both cases respondents favor AVoD and not TV. There is also a strong preference for Netflix-style PVoD when it comes to serial content, thus, competitive relations seem rather weak in this case in our sample. The analytical analysis further shows that the intensity of competition between the three types of services is not so clear at daytime. Here, users appear to use them not so much as alternatives. This is further supported by the results for the intention to bypass "waiting time", where our respondents clearly prefer one type of service - and not the one that theory would suggest (Netflix instead of YouTube). Not surprisingly, older generations strongly stick to traditional television, which merely points to a time-lag in the competition of newer technology-based services.

However, our empirical analysis shows that roughly 48 percent of the respondents view YouTube to be an alternative for TV (ranging from almost 20 percent among the over 60 years old to almost 70 percent from the below 20 years old; see section 3.2.1) - despite the strong differences in content. Notably, a strong minority of approx. 39 percent disagrees (ranging from more than 65 percent in the oldest to less than 20 percent in the youngest age group). Since our sample is biased towards younger and well-educated respondents, it can be expected that the disagreement figure may be higher in a more representative sample - for now, as in the course of time, the development will trend towards our results (emphasizing the now younger generations). Notwithstanding, the results make it hard to argue that YouTube is not exerting competitive pressure on traditional TV as some are claiming (see section 2). Our results expectably indicate to Netflix-type VoD services and TV being close competitors, whereas the picture for YouTube vs. Netflix is not so clear with 58 percent stating the view that they do not represent alternatives and almost 23 percent stating they do (without significant difference among the age groups; see section 3.2.1). However, at the same time, asked what medium they consume at prime time, for each type of service 70.6 percent or more of the respondents con- 
firmed consumption. ${ }^{12}$ The consequent indication that all three services compete for prime time attention is confirmed by analytical econometrics (see section 3.2.2). Thus, actual behavior (pseudo-revealed preferences through indirect questions) appears to show closer competition among the service types than (more directly) stated preferences.

Altogether, competitive pressure among Netflix, traditional TV and YouTube cannot be ignored when considering the development of markets for audiovisual contents - be it for competition policy or other purposes. Particularly, excluding YouTube from (analyses of) TV and/or VoD markets appears to inappropriate in this respect as it exerts considerable competition on the other two (types of) services. Especially for younger generations the competition for attention appears to be already strong today and will furthermore intensify in the course of time.

However, there are some limitations and caveats we need to consider. Some contents are not present on some type of services, for instance, hardly any contemporary music videos are nowadays broadcasted on TV and Netflix-style PVoD in Germany. ${ }^{13}$ The same is true for news on Netflix and co. This raises the questions: (i) does available content drive the answer in our survey, or (ii) does the consumption behavior/preferences we measure explain why there is virtually no content offering? Unfortunately, we cannot discriminate between these two possible explanations with our data. Still, this limitation is only relevant for some genre categories. Furthermore, anecdotic evidence for contemporary music videos shows that there was a considerable offer on TV (MTV, VIVA, etc.) until YouTube came up and only then the offer in TV started to vanish. This indicates that the non-offer may be a result of competition and, thus, towards explanation (ii). If this was valid, our results tend to underestimate the competitive pressure among the service types.

12 We included a question on second screen usage (i.e. parallel use of two screens) in our questionnaire. Although, younger consumers tend to engage in second screen usage like e.g. Instagram on the smartphone and Netflix on television at the same time, we consider the parallel usage of two videos to be a rare exception (mostly, due to overlapping audio tracks). Yet, future research is needed to investigate the phenomenon and better estimate the possibility of parallel usage.

13 For instance, MTV still broadcasts but its program does not primarily contend of music videos anymore. A channel like Deluxe Music does still broadcast music videos (mostly for older generations) but is of little relevance. 
With respect to news-style content, the results may reflect a dependence on the (perceived) quality of this type of content, about which information are not available in our data-set. Alternatively, the large-scale public service broadcaster landscape in Germany may already provide the overall market volume for audiovisual news contents, thus leaving no space for competition from newly emerging VoDservices, in particular given the fact that public service broadcasters (PSB) in Germany can subsidize their news coverage by revenues from a tax-like fee. Here, the demographic bias towards high educated respondents in our sample may influence the results since highly educated people are said to be more likely to value highlevel (PSB-) news contents.

Our results relate to the market offerings as they were in Germany at the time of the survey. For instance, the PVoD-style YouTube Premium was not relevant in Germany at the time of the survey (and still does not rack up considerable market shares at the time of writing) but may change competitive interrelations in the market in the future - as may other further dynamics. In particular, the entry of an advertising-financed Netflix-like service (contents like Netflix, revenue structure like free commercial TV) would represent a very different AVoD from YouTube and, thus, might lead to different results. Generally, the high market dynamics are likely to continue and may bring about a convergence of services with some players attempting to provide a one-stop shop for audiovisual consumption (e.g. Alphabet adding YouTube stories à la Instagram, video rental à la Amazon and premium subscription à la Netflix to its core AVoD business). These dynamics may further change competitive interrelations as well. Based on our analysis, we predict that further dynamics further increase the intensity of competition among services.

Finally, our results can only be seen as 'indication', since the sample is not representative in size, nature and scope. We have no data on 'real' consumption behavior, but personal statements about and estimations of consumption habits. It would be interesting to compare these results with data from YouTube or Netflix to see if actual consumption behavior and self-reporting match. However, since data is of major importance in that market and represents a relevant business secret, a publication by the companies cannot be expected. Future and complementary research might still find ways to track actual consumer behavior and analyze the 
(changing) dynamics in the field. Naturally, since it is the first empirical study on competition in VoD markets, follow up research and re-sampling are necessary to verify results.

\section{Conclusion and Implications}

The landscape of audiovisual content offerings and consumption is rapidly changing. Not long ago, it was dominated by linear television, transmitted terrestrially, through cable networks or via satellite. Recently, streaming services like Netflix, YouTube, Amazon Prime and others have emerged as new suppliers of audiovisual content. In this quickly changing industry, competition interrelations between the different formats are subject to controversy, in particular, with respect to YouTube exerting competitive pressure on services like Netflix and traditional TV. Based upon a survey with almost 3,000 participants, we provide an empirical analysis of consumption behavior of audiovisual contents. Using descriptive and analytical statistics, including multiple equation models, we are able to provide answers for and insights into our research questions. With respect to our general research question whether relevant competitive pressure between the services (in our study represented by YouTube, Netflix, TV) exists, our analysis demonstrates that all three (types of) services stand in competition with each other. Neglecting one type, like for instance YouTube, leads to a misrepresentation of competitive forces in the markets for audiovisual contents and to misleading interpretations. However, our rich data-set allows us to look deeper into the matter and specify the general research question by, more precisely, inquiring whether the intensity of competitive pressure depends on specific characteristics of demand, i.e. (i) for whom (e.g. age groups), (ii) during what time of the day (e.g. prime time), and (iii) for what purposes (e.g. genre, motivation/intention).

Regarding age groups, the battle between YouTube, Netflix and traditional TV mainly takes place regarding the younger generations for whom these services represent close alternatives, whereas older generations remain more focused on TV, probably due to a lack of adoption of new technologies. This also hints at further increasing competitive pressure among the services in the course of time. While 
these results confirm less detailed but sample-wise more representative studies, our result regarding different times of day represent novel insights. Our analysis shows that all three services strongly compete for prime-time consumption, i.e. the vast majority of consumers actively chooses between all three types when it comes to watch video content in the evening. However, our results for other times of day are mixed and insignificant. With respect to consumer intentions, we can show that the respondents in our sample preferred Netflix over the other two when it comes to "shortening waiting time", which represents a counterintuitive result to the expectation that YouTube would dominate this intention category.

Altogether and notwithstanding the general results of competitive pressure among all three types of services, our detailed analysis identifies pockets of more and such of less intensive competition within the battle among YouTube, Netflix and traditional TV. Furthermore, in some genres like sports, music video or news content, some of the services provide only remote or virtually no content. This may be the consequence of an overriding competitive advantage of one media type in this genre or due to the nature of the service type. However, in any case, the competitive pressure is comparably low in these cases - today. The ongoing dynamics of the analyzed markets imply that also competitive interrelations may be subject to further change in the future.

Our analysis yields important implications for the effects of cooperations, alliances, mergers and acquisitions in audiovisual content markets. It is not sufficient to point to differences in content or an alleged (and however defined) professionalism of content producers in order to assume a lack of competitive pressure. Also, features and characteristics of consumption behavior und competition from traditional TV markets can not readily be applied to more - offline and online - audiovisual content markets. Eventually, a general "they all compete because they all provide audiovisual content" would also be to superficial. Instead, our analysis demonstrates that audiovisual content providers act in a heterogeneous market where some suppliers may be closer competitors to each than to others (unilateral oligopoly effects; Kaplow \& Shapiro 2007; Froeb \& Werden 2008; Kerber \& Schwalbe 2008; Keating \& Willig 2015). Furthermore, consumption behavior is so differentiated that these interrelations may differ across, inter alia, daytimes, consumer intentions, and genres. 
Thus, a careful analysis of the actual competitive effects is necessary when assessing joint venture projects or mergers and acquisitions among these players, including vertical effects (which are not part of our analysis; but see e.g. Stöhr et al. 2020). Moreover, unilateral business strategies need to be observed and considered as well, in particular, if these strategies aim at or result in a walled garden type of offering, i.e. proceed in the direction of a closed ecosystem protected against outside (maverick) competition. This is necessary in order to sustain dynamic competition among audiovisual content providers and maintain a diverse, pluralistic, and preferenceconformal landscape.

\section{References}

Aguiar, Luis \& Waldfogel, Joel (2018), Netflix: Global Hegemon or Facilitator of Frictionless Digital Trade? Journal of Cultural Economics 42(3), 419-445.

Audience Project (2019), Insights 2019, Traditional TV, online video \& streaming, a study by the Audience Project, ed. by Rune Werliin, 1-55.

https://www.audienceproject.com/wp-content/uploads/ audienceproject_study_tv_video_streaming.pdf (accessed 2020-02-14).

Beisch, Natalie, Koch, Wolfgang \& Schäfer, Carmen (2019), ARD/ZDF-Onlinestudie 2019: Mediale Internetnutzung und Video-on-Demand gewinnen weiter an Bedeutung. Media Perspektiven 9/2019, 374-388.

Benes, Ross (2019), Users Still Demand Licensed Content from OTT Platforms, on eMarketer, 10.05.2019, https://www.emarketer.com/content/users-still-demandlicensed-content-from-ott-platforms (accessed 2020-03-03).

Berman, Saul, J., Battino, Bill, Shipnuck, Luisa \& Neus, Andreas (2009), The End of Advertising As We Know It, in: D. Gerbarg (ed.), Television goes Digital, New York: Springer, 29-56.

Boik, Andre, Greenstein, Shane M. \& Prince, Jeffrey (2017), The Empirical Economics of Online Attention. Kelley School of Business Research Paper No. 22427.

Briglauer, Wolfgang, Dürr, Niklas, Falck, Oliver, Hüschelrath, Kai (2019), Does state aid for broadband deployment in rural areas close the digital and economic divide? Information Economics and Policy 46 (3), 68-85. 
Bruns, Axel (2008), Blogs, Wikipedia, Second Life, and Beyond: From Production to Produsage, New York: Peter Lang.

Budzinski, Oliver \& Gaenssle, Sophia (2018), The Economics of Social Media Stars: An Empirical Investigation of Stardom, Popularity, and Success on YouTube. IImenau Economics Discussion Papers 24(112).

Budzinski, Oliver \& Kuchinke, Björn (2020), Industrial Organization of Media Markets and Competition Policy, in: Bjørn von Rimscha (ed.), Economics and Management of Communication, Berlin: DeGruyter, forthcoming.

Budzinski, Oliver \& Lindstädt-Dreusicke, Nadine (2020), Antitrust Policy in Video-onDemand Markets: The Case of Germany. Journal of Antitrust Enforcement, forthcoming.

Budzinski, Oliver \& Wacker, Katharina (2007), The Prohibition of the Proposed Springer-ProSiebenSat.1-Merger: How much Economics in German Merger Control? Journal of Competition Law and Economics 3(2), 281-306.

Bundeskartellamt (2011a), Beschluss in dem Verwaltungsverfahren ProSiebenSat.1 Media AG / RTL interactive GmbH, Aktenzeichen B6-94/10, http://www.bundeskartellamt.de/SharedDocs/Entscheidung/DE/Entscheidungen/F usionskontrolle/2011/B6-94-10.pdf?_blob=publicationFile\&v=3 (accessed 2019-10-28).

Bundeskartellamt (2011b), Bundeskartellamt Institutes Cartel Proceedings to Examine Video-on-demand Platform of Public Service Broadcasters, press release 2011-11-28,

http://www.bundeskartellamt.de/SharedDocs/Meldung/EN/Pressemitteilungen/20 11/28_11_2011_Germanys-Gold.html;jsessionid= 6D9A2CC003444E5ECBEDEAC771F19CE8.1_cid371? nn=3591568 (accessed 2019-10-28).

Bundeskartellamt (2015), Case Summary: ARD and ZDF Online Platform "Germany's Gold", B6-81/11-2, https://www.bundeskartellamt.de/SharedDocs/Entscheidung/EN/Fallberichte/Kart ellverbot/2015/B6-81-11.pdf?_blob=publicationFile\&v=2 (accessed 2019-1226). 
Chowdhury, Shaiful Alam \& Makaroff, Dwight (2013), Popularity Growth Patterns of YouTube Videos: A Category-based Study, in: K. H. Krempels \& A. Stocker (eds.), Proceedings of WEBIST 2013: 8th International Conference on Web Information Systems and Technologies, 233-242.

Dennhardt, Severin (2014), User-Generated Content and Its Impact on Branding, How User and Communities Create and Manage Brands in Social Media, Wiesbaden: Springer Gabler.

Ding, Yuan, Du, Yuan, Hu, Yingkai, Liu, Zhengye, Wang, Lugin, Ross, Keith \& Ghose, Anindya (2011), Broadcast Yourself: Understanding YouTube Uploaders, in: Patrick Thiran \& Walter Willinger Walter (eds.), IMC 2011, Proceedings of the 2011 ACM SIGCOMM on Internet Measurement Conference, New York: ACM, 361370.

Döring, Nicola (2014), Professionalisierung und Kommerzialisierung auf YouTube. merz medien + erziehung 58(4), 24-31.

El Khaoudi, Yassmine (2018), Deutscher Streaming-Markt: Netflix überholt Sky Amazon thront auf Platz 1. Chip Online, 21.10.2018, https://www.chip.de/news/Deutscher-Streaming-Markt-Netflix-ueberholt-SkyAmazon-thront-auf-Platz-1_150896945.html (accessed 2020-02-16).

Enli, Gunn \& Syvertsen, Trine (2016), The End of Television-Again! How TV Is Still Influenced by Cultural Factors in the Age of Digital Intermediaries. Media and Communication 4(3), 142-153.

Evans, David S. (2013), Attention Rivalry Among Online Platforms. Journal of Competition Law and Economics 9(2), 313-357.

Falkinger, Josef (2008), Limited Attention as a Scarce Resource in Information-Rich Economies. The Economic Journal 118, 1596-1620.

Fisher, Bill (2019), UK Digital Video 2019, A Rich Provider Landscape Drives Up Digital Viewership, on eMarketer, 19.09.2019, https://www.emarketer.com/content/uk-digital-video-2019 (accessed 2020-0213).

Froeb, Luke M. \& Werden, Gregory J. (2008), Unilateral Competitive Effects of Horizontal Mergers, in: Paolo Buccirossi (ed.), Handbook of Antitrust Economics, Boston: The MIT Press, 43-104. 
Fuchs, Christian (2014), Digital prosumption labour on social media in the context of the capitalist regime of time. Time \& Society 23 (1), 97-123.

Gaenssle, Sophia \& Budzinski, Oliver (2020), Stars in Social Media: New Light Through Old Windows? Journal of Media Business Studies, fothcoming.

Gaenssle, Sophia \& Kunz-Kaltenhäuser, Philipp (2020), What Drives BingeWatching? An Economic Theory and Analysis of Impact Factors, Conference Paper, Ilmenau.

Herrmann, Susanne (2019), Goldmedia Studie. Pay-VoD-Markt in Deutschland klar verteilt. W\&V Online, 30.10.2019,

https://www.wuv.de/medien/pay_vod_markt_in_deutschland_klar_verteilt (accessed 2020-02-14).

Kazakova, Snezhanka \& Cauberghe, Verolien (2013), Media Convergence and Media Multitasking, in: S. Diehl \& M. Karmasin (eds.), Media Convergence Management, Heidelberg: Springer, 177-188.

Kaplow, Louis \& Shapiro, Carl (2007), Antitrust, in: A. M. Polinsky \& S. Shavell (eds), Handbook of Law and Economics, Elsevier North Holland, 1073-1225.

Keating, Bryan \& Willig, Robert D. (2015), Unilateral Effects, in: Roger D. Blair \& D. Daniel Sokol (eds.), The Oxford Handbook of International Antitrust Economics, Vol. 1, Oxford: Oxford University Press, 466-508.

Kerber, Wolfgang \& Schwalbe, Ulrich (2008), Economic Principles of Competition Law, in: F. J. Säcker et al. (eds), Competition Law: European Community Practice and Procedure, London: Sweet \& Maxwell, 202-393.

Kupferschmitt, Thomas (2017), Onlinevideo-Reichweite und Nutzungsfrequenz wachsen, Altersgefälle bleibt, Ergebnisse der ARD/ZDF-Onlinestudie 2018. Media Perspektiven 9/2018, 427-437.

Krei, Alexander (2019), Geschäftszahlen 2018 vorgelegt, RTL Group will 350 Mio. Euro in Streaming investieren. DWDL, 13.03.2019, https://www.dwdl.de/nachrichten/71413/rtl_group_will_350_mio_euro_in_strea ming_investieren/?utm_source $=$ \&utm_medium $=$ \&utm_campaign $=$ \&utm_term $=$ (accessed 2020-02-06). 
Lindstädt-Dreusicke, Nadine \& Budzinski, Oliver (2020), The Video-on-demand Market in Germany - Dynamics, Market Structure and the (Special) Role of YouTube. Journal of Media Management and Entrepreneurship 2(1), 108-123. Ofcom (2018), Public Service Broadcasting in the Digital Age, https://www.ofcom.org.uk/_data/assets/pdf_file/0026/111896/Public-servicebroadcasting-in-the-digital-age.pdf (accessed 2019-12-26).

Revilla, Melanie A., Saris, Willem E. \& Krosnick, Jon A. (2014), Choosing the Number of Categories in Agree-disagree Scales. Sociological Methods \& Research 43(1), 73-97.

Richter, Felix (2019), The Generation Gap in TV Consumption, https://www.statista.com/chart/15224/daily-tv-consumption-by-us-adults/ (accessed 2020-02-13).

Ritzer, George \& Jurgenson, Nathan (2010), Production, Consumption, Prosumption: The Nature of Capitalism in the Age of the Digital Prosumer. Journal of Consumer Culture 10(1), 13-36.

Rubenking, Bridget, Bracken, Cheryl, Sandoval, Jennifer \& Rister, Alex (2018), Defining New Viewing Behaviours: What Makes and Motivates TV Bingewatching? International Journal of Digital Television 9(1), 69-85.

Simons, Nele (2015), TV Drama as a Social Experience: An Empirical Investigation of the Social Dimensions of Watching TV Drama in the Age of Non-linear Television. Communications 40(2), 219-236.

Statista (2018), Netflix Is Americans' Platform of Choice for TV Content, https://www.statista.com/chart/14559/americans-favorite-tv-platforms/, accessed 9th October 2019.

Statista (2020), Durchschnittliche tägliche Fernsehdauer in Deutschland nach Altersgruppen in den Jahren 2018 und 2019, based on AGF, GfK https://de.statista.com/statistik/daten/studie/152389/umfrage/durchschnittlichefernsehdauer-pro-tag/ (accessed 2020-02-13).

Steemers, Jeanette (2014), Selling Television: Addressing Transformations in the International Distribution of Television Content. Media Industries Journal, pp. 4449. 
Stöhr, Annika, Noskova, Victoriia, Kunz-Kaltenhäuser, Philipp, Gaenssle, Sophia \& Budzinski, Oliver (2020), Happily Ever After? - Vertical and Horizontal Mergers in the U.S. Media Industry, in: World Competition 43(1), 135-161.

Turek, Rasty (2019), What content dominates on YouTube?, https://blog.pex.com/what-content-dominates-on-youtube-390811c0932d, (accessed 2019-10-28).

Van den Bulck, Hilde \& Enli, Gunn Sara (2014), Flow under Pressure: Television Scheduling and Continuity Techniques as Victims of Media Convergence? Television \& New Media 15(5), 449-452.

W\&V (2019), Bilanz für 2018 und Ausblick, RTL Group verliert im TV - und investiert nun ins Streaming, in W\&V online, 14.03.2019, https://www.wuv.de/medien/rtl_group_verliert_im_tv_und_investiert_nun_ins_str eaming (accessed 2020-02-06).

YouTube Official Blog (2018), Introducing YouTube Premium, https://youtube.googleblog.com/2018/05/introducing-youtube-premium.html, (accessed 2019-10-28).

Zellner, Arnold (1962), An efficient method of estimating seemingly unrelated regressions and tests for aggregation bias. Journal of the American Statistical Association 57, 348-368.

Zellner, Arnold (1963), Estimators for seemingly unrelated regression equations: Some exact finite sample results. Journal of the American Statistical Association $58,977-992$.

Zellner, Arnold \& Huang, David S. (1962), Further properties of efficient estimators for seemingly unrelated regression equations. International Economic Review 3(3), 300-313. 


\section{Appendix}

\section{Appendix 1: Sample Income}

\begin{tabular}{|l|l|l|l|}
\hline Income & Freq. & Percent & Cum. \\
\hline \hline no response & 498 & 17.05 & 17.05 \\
\hline below 500 Euro & 416 & 14.25 & 31.30 \\
\hline $500-999$ Euro & 455 & 15.58 & 46.88 \\
\hline $1.000-1.499$ Euro & 278 & 9.52 & 56.40 \\
\hline $1.500-2.499$ Euro & 672 & 23.01 & 79.42 \\
\hline $2.500-2.999$ Euro & 241 & 8.25 & 87.67 \\
\hline $3.000-3.499$ Euro & 145 & 4.97 & 92.64 \\
\hline $3.500-3.999$ Euro & 84 & 2.88 & 95.51 \\
\hline $4.000-4.499$ Euro & 47 & 1.61 & 97.12 \\
\hline $4.500-4.999$ Euro & 28 & 0.96 & 98.08 \\
\hline 5.000 Euro and more & 56 & 1.92 & 100.00 \\
\hline \hline Total & 2,920 & 100.00 & \\
\hline
\end{tabular}

\section{Appendix 2: Sample Age Groups}

\begin{tabular}{|l|l|l|l|}
\hline Age & Freq. & Percent & Cum. \\
\hline \hline $10-19$ & 157 & 5.38 & 5.38 \\
\hline $20-29$ & 1,442 & 49.38 & 54.76 \\
\hline $30-39$ & 696 & 23.84 & 78.60 \\
\hline $40-49$ & 338 & 11.58 & 90.17 \\
\hline $50-59$ & 215 & 7.36 & 97.53 \\
\hline$>60$ & 72 & 2.47 & 100.00 \\
\hline \hline Total & 2,920 & 100.00 & \\
\hline
\end{tabular}




\title{
Diskussionspapiere aus dem Institut für Volkswirtschaftslehre
}

\author{
der Technischen Universität IImenau
}

Nr. 69 Budzinski, Oliver: Empirische Ex-Post Evaluation von wettbewerbspolitischen Entscheidungen: Methodische Anmerkungen, Januar 2012.

Nr. 70 Budzinski, Oliver: The Institutional Framework for Doing Sports Business: Principles of EU Competition Policy in Sports Markets, January 2012.

Nr. 71 Budzinski, Oliver; Monostori, Katalin: Intellectual Property Rights and the WTO, April 2012.

Nr. 72 Budzinski, Oliver: International Antitrust Institutions, Juli 2012.

Nr. 73 Lindstädt, Nadine; Budzinski, Oliver: Newspaper vs. Online Advertising Is There a Niche for Newspapers in Modern Advertising Markets?

Nr. 74 Budzinski, Oliver; Lindstädt, Nadine: Newspaper and Internet Display Advertising - Co-Existence or Substitution?, Juli 2012b.

Nr. 75 Budzinski, Oliver: Impact Evaluation of Merger Control Decisions, August 2012.

Nr. 76 Budzinski, Oliver; Kuchinke, Björn A.: Deal or No Deal? Consensual Arrangements as an Instrument of European Competition Policy, August 2012.

Nr. 77 Pawlowski, Tim, Budzinski, Oliver: The (Monetary) Value of Competitive Balance for Sport Consumers, Oktober 2012.

Nr. 78 Budzinski, Oliver: Würde eine unabhängige europäische Wettbewerbsbehörde eine bessere Wettbewerbspolitik machen?, November 2012.

Nr. 79 Budzinski, Oliver; Monostori, Katalin; Pannicke, Julia: Der Schutz geistiger Eigentumsrechte in der Welthandelsorganisation - Urheberrechte im TRIPS Abkommen und die digitale Herausforderung, November 2012.

Nr. 80 Beigi, Maryam H. A.; Budzinski, Oliver: On the Use of Event Studies to Evaluate Economic Policy Decisions: A Note of Caution, Dezember 2012.

Nr. 81 Budzinski, Oliver; Beigi, Maryam H. A.: Competition Policy Agendas for Industrializing Countries, Mai 2013.

Nr. 82 Budzinski, Oliver; Müller, Anika: Finanzregulierung und internationale Wettbewerbsfähigkeit: der Fall Deutsche Bundesliga, Mai 2013. 
Nr. 83 Doose, Anna Maria: Methods for Calculating Cartel Damages: A Survey, Dezember 2013.

Nr. 84 Pawlowski, Tim; Budzinski, Oliver: Competitive Balance and Attention Level Effects: Theore-tical Considerations and Preliminary Evidence, März 2014.

Nr. 85 Budzinski, Oliver: The Competition Economics of Financial Fair Play, März 2014.

Nr. 86 Budzinski, Oliver; Szymanski, Stefan: Are Restrictions of Competition by Sports Associations Horizontal or Vertical in Nature?, März, 2014.

Nr. 87 Budzinski, Oliver: Lead Jurisdiction Concepts Towards Rationalizing Multiple Competition Policy Enforcement Procedures, Juni 2014.

Nr. 88 Budzinski, Oliver: Bemerkungen zur ökonomischen Analyse von Sicherheit, August 2014.

Nr. 89 Budzinski, Oliver; Pawlowski, Tim: The Behavioural Economics of Competitive Balance: Implications for League Policy and Championship Management, September 2014.

Nr. 90 Grebel, Thomas; Stuetzer, Michael: Assessment of the Environmental Performance of European Countries over Time: Addressing the Role of Carbon, September 2014.

Nr. 91 Emam, Sherief; Grebel, Thomas: Rising Energy Prices and Advances in Renewable Energy Technologies, July 2014.

Nr. 92 Budzinski, Oliver; Pannicke, Julia: Culturally-Biased Voting in the Eurovision Song Contest: Do National Contests Differ?, December 2014.

Nr. 93 Budzinski, Oliver; Eckert, Sandra: Wettbewerb und Regulierung, März 2015.

Nr. 94 Budzinski, Oliver; Feddersen, Arne: Grundlagen der Sportnachfrage: Theorie und Empirie der Einflussfaktoren auf die Zuschauernachfrage, Mai 2015.

Nr. 95 Pannicke, Julia: Abstimmungsverhalten im Bundesvision Song Contest: Regionale Nähe versus Qualität der Musik, Oktober 2015.

Nr. 96 Budzinski, Oliver; Kretschmer, Jürgen-Peter: Unprofitable Horizontal Mergers, External Effects, and Welfare, October 2015.

Nr. 97 Budzinski, Oliver; Köhler, Karoline Henrike: Is Amazon The Next Google?, October 2015. 
Nr. 98 Kaimann, Daniel; Pannicke, Julia: Movie success in a genre specific contest: Evidence from the US film industry, December 2015.

Nr. 99 Pannicke, Julia: Media Bias in Women's Magazines: Do Advertisements Influence Editorial Content?, December 2015.

Nr. 100 Neute, Nadine; Budzinski, Oliver: Ökonomische Anmerkungen zur aktuellen Netzneutralitätspolitik in den USA, Mai 2016.

Nr. 101 Budzinski, Oliver; Pannicke, Julia: Do Preferences for Pop Music Converge across Countries? - Empirical Evidence from the Eurovision Song Contest, Juni 2016.

Nr. 102 Budzinski, Oliver; Müller-Kock, Anika: Market Power and Media Revenue Allocation in Professonal Sports: The Case of Formula One, Juni 2016.

Nr. 103 Budzinski, Oliver: Aktuelle Herausforderungen der Wettbewerbspolitik durch Marktplätze im Internet, September 2016.

Nr. 104 Budzinski, Oliver: Sind Wettbewerbe im Profisport Rattenrennen?, Februar 2017.

Nr. 105 Budzinski, Oliver; Schneider, Sonja: Smart Fitness: Ökonomische Effekte einer Digitalisierung der Selbstvermessung, März 2017.

Nr. 106 Budzinski, Oliver; Pannicke, Julia: Does Popularity Matter in a TV Song Competition? Evidence from a National Music Contest, April 2017.

Nr. 107 Budzinski, Oliver; Grusevaja, Marina: Die Medienökonomik personalisierter Daten und der Facebook-Fall, April 2017.

Nr. 108 Budzinski, Oliver: Wettbewerbsregeln für das Digitale Zeialter - Die Ökonomik personalisierter Daten, Verbraucherschutz und die 9.GWB-Novelle, August 2017.

Nr. 109 Budzinski, Oliver: Four Cases in Sports Competition Policy: Baseball, Judo, Football, and Motor Racing, September 2017.

Nr. 110 Budzinski, Oliver: Market-internal Financial Regulation in Sports as an Anticompetitive Institution, October 2017.

Nr. 111 Bougette, Patrice; Budzinski, Oliver; Marty, Frédéric: EXPLOITATIVE ABUSE AND ABUSE OF ECONOMIC DEPENDENCE: WHAT CAN WE LEARN FROM THE INDUSTRIAL ORGANIZATION APPROACH?, December 2017.

Nr. 112 Budzinski, Oliver; Gaenssle, Sophia: The Economics of Social Media Stars: An Empirical Investigation of Stardom, Popularity, and Success on YouTube, Januar 2018. 
Nr. 113 Gaenssle, Sophia; Budzinski, Oliver; Astakhova Daria: Conquering the Box Office: Factors, influencing Success of International Movies in Russia, Mai 2018.

Nr. 114 Budzinski, Oliver; Stöhr, Annika: Die Ministererlaubnis als Element der deutschen Wettbewerbsordnung: eine theoretische und empirische Analyse, Juli 2018.

Nr. 115 Budzinski, Oliver; Kuchinke, Björn A.: Modern Industrial Organization Theory of Media Markets and Competition Policy Implications, September 2018.

Nr. 116 Budzinski, Oliver; Lindstädt-Dreusicke, Nadine: The New Media Economics of Video-on-Demand Markets: Lessons for Competition Policy, Oktober 2018.

Nr. 117 Budzinski, Oliver; Stöhr, Annika: Competition Policy Reform in Europe and Germany - Institutional Change in the Light of Digitization, November 2018.

Nr. 118 Budzinski, Oliver; Noskova, Victoriia; Zhang, Xijie: The Brave New World of Digital Personal Assistants: Benefits and Challenges from an Economic Perspective, December 2018.

Nr. 119 Bougette, Patrice; Budzinski, Oliver \& Marty, Frédéric: EXPLOITATIVE ABUSE AND ABUSE OF ECONOMIC DEPENDENCE: WHAT CAN WE LEARN FROM AN INDUSTRIAL ORGANIZATION APPROACH? [Updated Version 2018], December 2018.

Nr. 120 Bartelt, Nadja: Bundling in Internetmärkten - Ökonomische Besonderheiten, Wettbewerbseffekte und Regulierungsimplikationen, Dezember 2018.

Nr. 121 Budzinski, Oliver; Feddersen, Arne: Measuring Competitive Balance in Formula One Racing, März 2019.

Nr. 122 Budzinski, Oliver; Kohlschreiber, Marie; Kuchinke, Björn A. \& Pannicke, Julia: Does Music Quality Matter for Audience Voters in a Music Contest, März 2019.

Nr. 123 Gaenssle, Sophia; Budzinski, Oliver: Stars in Social Media: New Light Through Old Windows?, April 2019.

Nr. 124 Stöhr, Annika; Budzinski, Oliver: Ex-post Analyse der MinistererlaubnisFälle - Geminwohl durch Wettbewerbsbeschränkungen?, April 2019. 
Nr. 125 Budzinski, Oliver; Lindstädt-Dreusicke, Nadine: The New Media Economics of Video-on-Demand Markets: Lessons for Competition Policy (Updated Version), May 2019.

Nr. 126 Stöhr, Annika; Noskova, Victoriia; Kunz-Kaltenhäuser, Philipp; Gaenssle, Sophia \& Budzinski, Oliver: Happily Ever After? - Vertical and Horizontal Mergers in the U.S. Media Industry, June 2019.

Nr. 127 Budzinski, Oliver; Stöhr, Annika: Der Ministererlaubnis-Fall Miba/Zollern: Europäische Champions statt Wettbewerb?, Juni 2019.

Nr. 128 Budzinski, Oliver; Gaenssle, Sophia \& Kunz-Kaltenhäuser, Philipp: How Does Online Streaming Affect Antitrust Remedies to Centralized Marketing? The Case of European Football Broadcasting, Rights, July 2019.

Nr. 129 Budzinski, Oliver; Haucap, Justus: Kartellrecht und Ökonomik: Institutions Matter!, July 2019.

Nr. 130 Budzinski, Oliver \& Stöhr, Annika: Public Interest Considerations in European Merger Control Regimes, August 2019.

Nr. 131 Gaenssle, Sophia; Budzinski, Oliver \& Astakhova: Daria: Conquering the Box Office: Factors Influencing Succes of International Movies in Russia (Update), October 2019.

Nr. 132 Stöhr, Annika; Budzinski, Oliver \& Jasper, Jörg: Die Neue E.ON auf dem deutschen Strommarkt - Wettbewerbliche Auswirkungen der innogyÜbernahme, November 2019.

Nr. 133 Budzinski, Oliver; Grebel, Thomas; Wolling, Jens \& Zhang, Xijie: Drivers of Article Processing Charges in Open Access, December 2019.

Nr. 134 Gaenssle, Sophia; Kuchinke, Björn, A.: Die Hörspielserie „Die drei ???” Der wirtschaftliche Erfolg und Gründe dafür, Januar 2020.

Nr. 135 Budzinski, Oliver: The Economics of International Competition Policy: New Challenges in the Light of Digitization?, January 2020.

Nr. 136 Dittmann, Heidi \& Kuchinke, Björn A.: Die Theorie mehrseitiger Marktplätze in der US-amerikanischen und deutschen Zusammenschlusskontrolle: Eine empirische Untersuchung für den Mediensektor, Januar 2020. 